\title{
Effect of Site-Specific Integrated Nutrient Management on Soil Fertility under Cotton-Wheat Cropping System of Punjab Pakistan
}

\author{
Muhammad Akram Qazi*, Naveed Iqbal Khan \\ Soil Fertility Research Institute, Lahore, Punjab, Pakistan
}

Received: 5 January 2020

Accepted: 16 March 2020

\begin{abstract}
Cotton-wheat rotation is one of the profitable cropping systems under arid climatic conditions in the agro-ecosystem of Punjab, Pakistan. The cropping system's productivity factor is decreasing and is considered primarily due to imbalanced and non-integrated use of nutrients without taking care of soil health measures. Exploring the role of integrated site-specific nutrient management plans, treatments containing 2 fertilizer doses, and 3 management techniques on soil organic matter (SOM), soil $\mathrm{P} \&$ soil $\mathrm{K}$ were studied in the cotton-wheat system of Punjab Pakistan for six crop seasons on a permanent layout. Substantial increase of $54-70 \%$ in SOM over the initial level of $5.0 \mathrm{~g} \mathrm{Kg}^{-1}$ in sandy loam soil was observed by adapting integrated nutrients management (INM) techniques. Similarly, significantly improved level of soil test phosphorus STP was observed at the end of the sixth crop season and INM techniques resulted in a $429 \%$ to $453 \%$ increase in STP. However, statistical analysis revealed a non-significant effect of doses, and a significant declining effect on soil $\mathrm{K}$ was observed with the applied technique of only mineral fertilizer application. Highly negative $\mathrm{K}$ balance suggests that the system will not be able to sustain the long-term supply of $\mathrm{K}$. Ranking of indices from the best to the least favorable was recorded as $\mathrm{P}>\mathrm{SOM}>\mathrm{K}$.
\end{abstract}

Keywords: mineral fertilizer, INM, cotton-wheat cropping system, site-specific, MSWC

\section{Introduction}

Cotton-wheat rotation is one of the profitable cropping systems under arid climatic conditions in the agro-ecosystem of Punjab, Pakistan. Subsequently, the soils of this system have been subjected to conventional exploitative agriculture over a long period of time and as such cannot sustain soil fertility and fulfill the

*e-mail: makramqazi@gmail.com nutritional requirements of improved crop varieties. To meet the demands of the quickly increasing population, it is enormously needed to produce more grains (food) and fiber. At the same time, agriculture of the country is facing fierce competition for land, water and other natural resources with other sectors, including industry and urbanization. Since more and more land is lost to non-agricultural purposes and to land degradation, the increase in food demand has to be met by increasing yields from the existing land resources. Crop intensification is the main vehicle for increasing food 
output [1]. However, intensive cultivation with high yielding crop varieties augmented with unscrupulous use of mineral fertilizers has led to the depletion of soil organic matter (SOM) contents and the degradation of soil quality [2]. It is reported [3, 4] that soils of a vast area of Pakistan is extremely poor in organic matter which has appeared to be the main cause of crop yield stagnation [5]. Chemical fertilizers in combination with organic manures can be effectively used to level off the yield stagnation [6]. Because organic amendments have the potential to ameliorate the threat of climate change and seasonal variation to food security [7]. The efficient use of chemical fertilizers requires an optimum level of organic matter in the soil that can be achieved by integrated use of chemical and organic fertilizers including composts [8-10]. Hence, to sustain a cropping system, an effective and efficient fertilizer application as per need is required [11]. Soil test based fertilizer application can play a pivotal role due to its ability to determine fertilizer need for sowing of a crop $[12,13]$. Excessive application of organic manure should be avoided, particularly in soil, to reduce the risk of toxic effects from reduced metabolic intermediates [14]. A crucial productivity factor of continuous and imbalanced use of fertilizers, is adversely affecting the sustainability of a cropping system besides degrades the soil health and quality hence causing environmental pollution [15-18]. Soil organic matter (SOM) is well known to enhance the physical, chemical, and biological properties of soil and is widely regarded as a key indicator of soil health [19, 20]. Therefore, this is high time to realize that this crop production system is depleting our environment and ecosystem $[6,21]$. The major issue is the rational use of inorganic and organic inputs because only organic sources cannot meet the total nutrient requirements of modern agriculture, hence integrated use of nutrients from inorganic and organic sources will be the need of the time $[22,23,11]$.

Use of mineral fertilizers with organic matter in suitable ratios is known as integrated nutrient management (INM) [24]. The indexation technique can be efficiently and effectively used to evaluate the effects of INM in a cropping system on the quality of soil and crop yield [24, 25]. Cotton-wheat cropping system is considered a "grain plus cash" cropping system [26]. Cotton is sold as an industrial product and increases farmers' income while wheat improves food security [27]. These crops contribute greatly to improve the economic conditions of a large number of people engaged in farming, processing trade, and the textile industry [28]. This study is first of its kind in Pakistan and will provide appropriate ratio/plan of combined application of inorganic and organic fertilizer in cotton -wheat cropping system, data base for future research work and guidelines for policy makers.

\section{Materials and Methods}

Six field experiments on a permanent layout were conducted for six crop seasons in the cotton-wheat cropping system in order to assess the effect of various applied treatments. Detail of the work plan is briefly given below.

\section{Site for Study and Initial Soil Characteristics}

Field experiments were conducted for three years at Cotton Research Sub-Station, Raiwind, Lahore $\left(31.23886^{\circ} \mathrm{N}\right.$ and $\left.74.21686^{\circ} \mathrm{E}\right)$ to investigate the effects of integrated organic and inorganic fertilizers in a cropping system on SOM, P and $\mathrm{K}$. Crops were irrigated with both canal as well as tube well water as per requirement. The experimental site was under continuous cotton-wheat cropping system for long and was 228 meters above mean sea level and initial soil characteristics are given in Table 1 .

\section{Management Techniques and Fertilizer Doses}

Three management techniques ( $T_{-}$: Only use of mineral fertilizer, $T_{-I I}$ INM of organic and mineral fertilizer in 1:4 with application of pesticides and herbicides and $T_{-I I I}$ : INM of organic and mineral fertilizer in 1:4 without application of pesticides and herbicides) and two mineral fertilizer doses $\left(D_{-I}\right.$. Conventional mineral fertilizer $\mathrm{P}$ application according to the current recommendation of the extension service without caring soil test value and $D_{-I I}$ : Site-specific mineral fertilizer $\mathrm{P}$ application on the soil test basis) were evaluated in the form of following combinations.

Table 1. Initial soil characteristics.

\begin{tabular}{|c|c|c|c|c|c|c|c|c|c|}
\hline Depth & EC & $\mathrm{pH}$ & $\mathrm{OM}$ & $\mathrm{P}$ & $\mathrm{K}$ & Sand & Silt & Clay & Textural Class \\
\hline $\mathrm{Cm}$ & $\mathrm{dS} \mathrm{m}{ }^{-1}$ & - & $\%$ & \multicolumn{2}{|c|}{$\mathrm{ppm}$} & \multicolumn{4}{|c|}{$\%$} \\
\hline $0-15$ & 0.9 & 8.0 & 0.50 & 1.70 & 129.0 & 64.4 & 21.2 & 14.4 & Sandy loam \\
\hline $15-30$ & 0.9 & 7.9 & 0.35 & 1.00 & 122.0 & 59.6 & 28.2 & 12.2 & Sandy Loam \\
\hline
\end{tabular}

P fixation factor $=3.0$ 


\begin{tabular}{|c|c|c|}
\hline Treatment & Treatment Type & Description \\
\hline$T_{-I} \times D_{-I}$ & Conventional & $\begin{array}{l}\text { Conventional mineral fertilizer P application according to the current recommendation of } \\
\text { the extension service without caring soil test value }\end{array}$ \\
\hline$T_{-I} \times D_{-I I}$ & Site-specific & Site-specific mineral fertilizer $\mathrm{P}$ application on soil test $\mathrm{P}$ basis \\
\hline$T_{-I I} \times D_{-I}$ & Conventional Organic & $\begin{array}{c}\text { Conventional way of integrated fertilizer use (INM of organic and mineral fertilizer in 1:4 } \\
\text { on soil test P basis) with pesticides and herbicides. }\end{array}$ \\
\hline$T_{-I I} \mathrm{X} D_{-I I}$ & Site-specific Organic & $\begin{array}{c}\text { Site-specific way of integrated fertilizer use (INM of organic and mineral fertilizer in 1:4 } \\
\text { on soil test P basis) with pesticides and herbicides. }\end{array}$ \\
\hline$T_{-I I I} \times D_{-I}$ & $\begin{array}{l}\text { Conventional Organic } \\
\text { without pesticides }\end{array}$ & $\begin{array}{c}\text { Conventional way of integrated fertilizer use (INM of organic and mineral fertilizer in 1:4 } \\
\text { on soil test P basis) without pesticides and herbicides. }\end{array}$ \\
\hline$T_{-I I I} \times D_{-I I}$ & $\begin{array}{l}\text { Site-specific Organic } \\
\text { without pesticide use }\end{array}$ & $\begin{array}{l}\text { Site-specific way of integrated fertilizer use (INM of organic and mineral fertilizer in 1:4 } \\
\text { on soil test P basis) without pesticides and herbicides. }\end{array}$ \\
\hline
\end{tabular}

\section{Mineral Fertilizer Application Rates}

The detail of mineral fertilizers applied in permanent field during three years in six crop seasons are given in Table 2.

\section{Application Rates of Organic Fertilizer (MSWC)}

The MSWC was prepared aerobically by M/S Waste Busters Pvt Ltd. Lahore, Punjab, Pakistan. MSWC application was made on the basis of $\mathrm{P}$ requirement of a crop in each treatment. A computed quantity of MSWC was integrated in a respective fertilizer dose in 1:4 (MSWC: Mineral fertilizer) on soil test P basis. Singer et al., 2004 [29]. emphasized phosphorus based application rather than nitrogen based application of compost in order to avoid loading of contaminants particularly phosphorus. In Punjab, Pakistan, the $\mathrm{P}$ sufficiency soil level (Olsen sodium bicarbonate extractable) was recommended as $21 \mathrm{ppm}$ [30]. The MSWC analysis depicted that it contained organic matter $40 \%$, nitrogen \& phosphorus $0.50 \%$ and potassium $1.00 \%$, zinc $2.0 \mathrm{ppm}$, copper $0.5 \mathrm{ppm}$, Iron $20.0 \mathrm{ppm}$, manganese $1.0 \mathrm{ppm}$, lead $0.1 \mathrm{ppm}$, Nickle $0.05 \mathrm{ppm}$, cobalt
$0.05 \mathrm{ppm}$, cadmium $0.05 \mathrm{ppm}$ and chromium 0.05 ppm on dry-weight basis. The MSWC application to each treatment in every season is presented in Table 3. McLean prediction model for site-specific $\mathrm{P}$ application was followed [31].

\section{Analysis of Soil Characteristics}

The following methods were used for analysis.

\begin{tabular}{|c|c|c|}
\hline $\begin{array}{l}\text { Sr. } \\
\text { No. }\end{array}$ & Parameter & Method Followed \\
\hline 1. & SOM & $\begin{array}{c}\text { [32] (Walkley and Black, } \\
\text { 1934) }\end{array}$ \\
\hline 2. & Soil Phosphorus & [33] (Olsen et al., 1954) \\
\hline 3. & Soil Potassium & $\begin{array}{c}\text { [34] (Brown and Warncke, } \\
1988)\end{array}$ \\
\hline 4. & $\begin{array}{c}\text { Phosphorus and } \\
\text { potassium balance in } \\
\mathrm{kg} \mathrm{ha}^{-1}\end{array}$ & $\begin{array}{c}\mathrm{P} \text { or } \mathrm{K} \text { balance }=\sum \text { (Fertilizer } \\
\mathrm{P} \text { or } \mathrm{K} \text {, municipal solid waste } \\
\text { manure } \mathrm{P} \text { or } \mathrm{K} \text {, irrigation } \\
\text { water } \mathrm{P} \text { or } \mathrm{K})-\mathrm{Plant} \mathrm{P} \text { or } \mathrm{K} \\
(\mathrm{P} \text { or } \mathrm{K} \text { removal by grain and } \\
\text { straw) }\end{array}$ \\
\hline
\end{tabular}

Table 2. Mineral fertilizer application rates.

\begin{tabular}{|c|c|c|c|c|c|c|c|}
\hline \multirow{3}{*}{ Crop detail } & \multirow{3}{*}{$\begin{array}{l}\text { Soil P } \\
(\mathrm{ppm})\end{array}$} & \multicolumn{6}{|c|}{ Mineral Fertilizer Application Rate $\left(\mathrm{kg} \mathrm{ha}^{-1}\right)$} \\
\hline & & \multicolumn{3}{|c|}{$D_{-I}($ Conventional $)$} & \multicolumn{3}{|c|}{$D_{-I I}($ Site-Specific) } \\
\hline & & $\mathrm{N}$ & $\mathrm{P}_{2} \mathrm{O}_{5}$ & $\mathrm{~K}_{2} \mathrm{O}$ & $\mathrm{N}$ & $\mathrm{P}_{2} \mathrm{O}_{5}$ & $\mathrm{~K}_{2} \mathrm{O}$ \\
\hline Wheat, $1^{\text {st }}$ Crop & 1.7 & 135 & 100 & 40 & 135 & 196 & 40 \\
\hline Cotton, $1^{\text {st }}$ Crop & 9.4 & 115 & 85 & 35 & 115 & 91 & 35 \\
\hline Wheat, $2^{\text {nd }}$ Crop & 14.6 & 135 & 100 & 40 & 135 & 91 & 40 \\
\hline Cotton, $2^{\text {nd }}$ Crop & 17.8 & 115 & 85 & 35 & 115 & 82 & 35 \\
\hline Wheat, $3^{\text {rd }}$ Crop & 16.7 & 135 & 100 & 40 & 135 & 59 & 40 \\
\hline Cotton, $3^{\text {rd }}$ Crop & 14.7 & 115 & 85 & 35 & 115 & 19 & 35 \\
\hline \multicolumn{2}{|c|}{ Total } & 750 & 555 & 225 & 750 & 538 & 225 \\
\hline
\end{tabular}


Table 3. Detail of MSWC application to soil.

\begin{tabular}{|c|c|c|c|c|c|c|c|}
\hline \multirow{2}{*}{$\begin{array}{c}\text { Combination of } \\
\text { Techniques and } \\
\text { Doses }\end{array}$} & $\begin{array}{c}\text { Wheat-1 } \\
\text { Soil test P at } \\
\text { sowing } \\
=1.70 \mathrm{mg} \mathrm{kg}\end{array}$ & $\begin{array}{c}\text { Cotton-1 } \\
\text { Soil test P at } \\
\text { sowing } \\
=9.40 \mathrm{mg} \mathrm{kg}\end{array}$ & $\begin{array}{c}\text { Wheat-2 } \\
\text { Soil test P at } \\
\text { sowing } \\
=9.40 \mathrm{mg} \mathrm{kg}{ }^{-1}\end{array}$ & $\begin{array}{c}\text { Cotton-2 } \\
\text { Soil test P at } \\
\text { Sowing } \\
=10.0 \mathrm{mg} \mathrm{kg}^{-1}\end{array}$ & $\begin{array}{c}\text { Wheat-3 } \\
\text { Soil test P at } \\
\text { sowing } \\
=11.70 \mathrm{mg} \mathrm{kg}^{-1}\end{array}$ & $\begin{array}{c}\text { Cotton-3 } \\
\text { Soil test P at } \\
\text { sowing } \\
=14.60 \mathrm{mg} \mathrm{kg}^{-1}\end{array}$ & $\begin{array}{c}\text { Cumulative } \\
\text { Amount }\end{array}$ \\
\hline $\begin{array}{c}T_{-I} X D_{-I} \text { and } \\
T_{-I} X D_{-I I}\end{array}$ & 0 & 0 & 0 & 0 & 0 & 0 & 0 \\
\hline $\begin{array}{c}T_{-I I} X D_{-I} \text { and } \\
T_{-I I I} X D_{-I}\end{array}$ & 4000 & 3400 & 4000 & 3400 & 4000 & 3400 & 22200 \\
\hline $\begin{array}{c}T_{-I I} X D_{-I I} \text { and } \\
T_{-I I} X D_{-I I}\end{array}$ & 7800 & 3600 & 3600 & 3400 & 2400 & 800 & 21600 \\
\hline
\end{tabular}

\section{Indexation}

Indices were calculated in respect of SOM, P and $\mathrm{K}$. The index value of each characteristic of a cropping system was determined as the ratio the improved characteristic to that of conventional characteristic. For example, the index of SOM was determined as "SOM because of INM/SOM due to only mineral fertilizer application".

If the value of index is more than one indicates positive role/effect, if the value of index is less than one indicates negative role/effect and if the value of index is equal to one indicates no change as described by Eltun et al., (2002) [35].

Table 4. Soil OM, P and K status after three years of experimentation.

\begin{tabular}{|c|c|c|c|c|c|c|}
\hline Treatments & $\begin{array}{c}\text { SOM } \\
(\%)\end{array}$ & $\begin{array}{c}\text { \% Increase over } \\
\text { initial SOM level } \\
(0.50 \%)\end{array}$ & $\begin{array}{c}\mathrm{P}_{2} \mathrm{O}_{5} \\
(\mathrm{ppm})\end{array}$ & $\begin{array}{l}\text { \% Increase over } \\
\text { initial STP level } \\
\qquad(1.7 \mathrm{ppm})\end{array}$ & $\begin{array}{c}\mathrm{K}_{2} \mathrm{O} \\
(\mathrm{ppm})\end{array}$ & $\begin{array}{c}\text { \% Increase over initial } \\
\text { soil K level (129.0 } \\
\text { ppm) }\end{array}$ \\
\hline \multicolumn{7}{|c|}{ Fertilizer doses } \\
\hline$D_{-I .}$ Conventional & $0.77 \mathrm{~b}$ & 54 & $8.4 \mathrm{~b}$ & 394 & $121 \mathrm{a}$ & -6.2 \\
\hline$D_{-I I .}$ Site-specific & $0.85 \mathrm{a}$ & 70 & $9.5 \mathrm{a}$ & 459 & $124 \mathrm{a}$ & -3.87 \\
\hline LSD .05 & 0.063 & & 0.82 & & 6.2 & \\
\hline$\%$ increase over $D_{-I .}$ & 10.38 & & 13.09 & & 2.48 & \\
\hline \multicolumn{7}{|c|}{ Management Techniques } \\
\hline$T_{-I .}$ Only Mineral fertilizer & $0.74 \mathrm{~b}$ & 48 & $8.5 \mathrm{a}$ & 400 & $116 \mathrm{~b}$ & -10.1 \\
\hline$T_{-I I .}$ INM with pesticides & $0.82 \mathrm{a}$ & 64 & $9.0 \mathrm{a}$ & 429 & $123 \mathrm{ab}$ & -4.70 \\
\hline$T_{-I I I .}$ INM without pesticides & $0.88 \mathrm{a}$ & 76 & $9.4 \mathrm{a}$ & 453 & $129 \mathrm{a}$ & 0 \\
\hline LSD .05 & 0.077 & & 0.99 & & 7.6 & \\
\hline$\%$ increase in $\mathrm{T}_{-I I}$ over $\mathrm{T}_{-I}$ & 18.92 & & 10.59 & & 11.21 & \\
\hline$\%$ increase in $\mathrm{T}_{-I I}$ over $\mathrm{T}_{-I}$ & 10.81 & & 5.88 & & 6.03 & \\
\hline \multicolumn{6}{|c|}{ Season } & \\
\hline Wheat, $1^{\text {st }}$ Crop & $0.93 \mathrm{a}$ & 86 & $7.1 \mathrm{e}$ & 318 & $114 \mathrm{c}$ & -11.63 \\
\hline Cotton, $1^{\text {st }}$ Crop & $0.82 \mathrm{~b}$ & 64 & $8.8 \mathrm{~d}$ & 417 & $103 \mathrm{~d}$ & -20.16 \\
\hline Wheat, $2^{\text {nd }}$ Crop & $0.68 \mathrm{c}$ & 36 & $9.7 \mathrm{~cd}$ & 470 & $131 \mathrm{~b}$ & 1.55 \\
\hline Cotton, $2^{\text {nd }}$ Crop & $1.01 \mathrm{a}$ & 102 & $11.1 \mathrm{bc}$ & 552 & $158 \mathrm{a}$ & 22.48 \\
\hline Wheat, $3^{\text {rd }}$ Crop & $0.68 \mathrm{c}$ & 36 & $14.8 \mathrm{a}$ & 770 & $133 \mathrm{~b}$ & 3.10 \\
\hline Cotton, $3^{\text {rd }}$ Crop & $0.75 \mathrm{bc}$ & 50 & $12.1 \mathrm{~b}$ & 611 & $94 \mathrm{~d}$ & -27.13 \\
\hline LSD .05 & 0.085 & & 1.41 & & 8.2 & \\
\hline Last $\%$ increase over Initial status & 50.00 & & 611.76 & & -27.13 & \\
\hline
\end{tabular}

Figures sharing same alphabet are not significantly different from each other 


\section{Design and Analysis}

The data were subjected to analysis of variance. A combination of techniques and doses effect was studied on SOM, P \& K in cotton-wheat system by considering as one unit and unit was replicated thrice in a split plot design by using statistical software "CoStat 6.451".

\section{Results and Discussion}

The results of field experiments for six seasons are discussed hereafter according to treatments effect on SOM, Phosphorus, and Potassium.

\section{Changes in Soil Organic Matter (SOM)}

Total application of MSWC was 22.0 tons $\mathrm{ha}^{-1}$ (Table 3) during three years in applied treatments resulted in $64 \%$ to $76 \%$ increase in SOM over an initial level of $0.5 \%$ to a level of 0.82 to $0.88 \%$ by both management techniques ( $T_{-I I}$ and $T_{-I I}$ ) of INM with and without pesticide use (Table 4). The only mineral fertilizer application in $T_{-I}$ increased $48 \%$ SOM. The performance of $T_{-I I}$ and $T_{-I I I}$ over $T_{-I}$ is $18.92 \%$ and $10.81 \%$ respectively in enhancing SOM level, while, conventional $\left(D_{-I}\right)$ and site-specific $\left(D_{-I I}\right)$ doses enhanced SOM level $54 \%$ and $70 \%$ respectively. Site-specific $\left(D_{-I I}\right)$ dose performed $10.38 \%$ better in enhancing SOM level as compared to conventional $\left(D_{-I}\right)$. By season's interpretation, $50 \%$ increase in $\mathrm{SOM}$ was observed after the harvest of final cotton crop. It is important to note that season's effect is significantly different in different crop seasons. It was also noticed that initial improvement in SOM was up till second cotton harvest, afterward status decreased or sustained. But in all seasons, values were higher than initial status. It counts as high attainment that the increase in SOM was taken place in an exhaustive cropping system of semi-arid to arid climate especially through INM. Rate of increase of SOM over initial level in six crop seasons after crop harvest is depicted in Fig. 1.

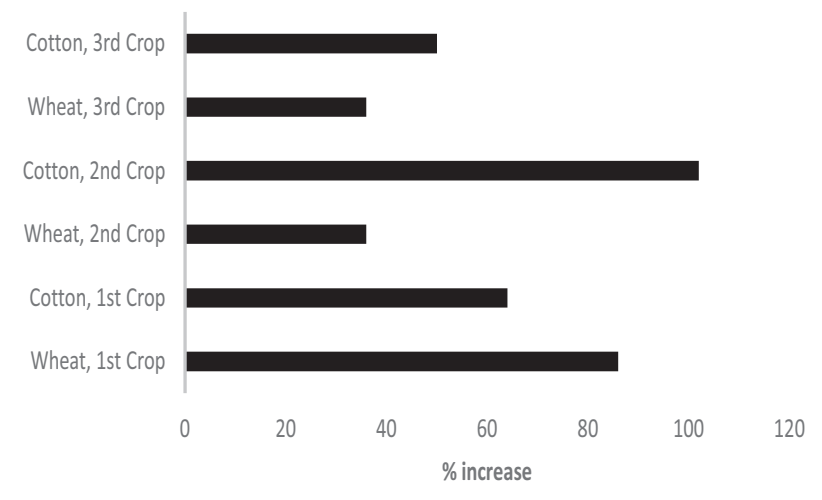

Fig. 1. \% Increase of SOM over initial level in six crop seasons.

\section{Changes in Soil Phosphorus}

The marked beneficial effects of MSWC application on STP level were observed in this system. Statistical significant improved soil test phosphorus (STP) level was observed by the site-specific way of fertilizer application $\left(D_{-I I}\right)$ over conventional fertilizer application $\left(D_{-I}\right)$ after three years. The conventional $\left(D_{-I}\right)$ and sitespecific $\left(D_{-I I}\right)$ doses enhanced soil test phosphorus (STP) level $394 \%$ and $459 \%$ respectively over initial level. Comparison of two doses revealed that $13.00 \%$ increase was due to site-specific way of fertilizer application over conventional fertilizer application (Table 4) in spite of the fact site-specific way of fertilizer application received less i.e. $\mathrm{P}_{2} \mathrm{O}_{5}$ i.e. $538 \mathrm{~kg} \mathrm{ha}^{-1}$ as compared to conventional fertilizer application which received $\mathrm{P}_{2} \mathrm{O}_{5}$ i.e. $555 \mathrm{~kg} \mathrm{ha}^{-1}$ in three years (Table 2). Total application of MSWC was 21.6-22.0 tons ha ${ }^{-1}$ (Table 3) during three years in INM techniques resulted in $429 \%$ to $453 \%$ increase in STP over an initial level of $1.70 \%$ to a level of $9.0 \mathrm{ppm}$ and $9.40 \mathrm{ppm}$ by both management techniques $\left(T_{-I I}\right.$ and $\left.T_{-I I}\right)$ of INM with and without pesticide use (Table 4). The only mineral fertilizer application in $T_{-I}$ also increased $400 \%$ STP level. By season's interpretation, $612 \%$ increase in STP level was observed after the harvest of final cotton crop (Table 4). It was also noticed that gradual improvement in STP level was up till third wheat crop harvest, the afterward status was found decreased. But in all seasons, values were much higher than initial status. It counts as significant attainment that the increase in STP level was taken place in an exhaustive cropping system of arid to semiarid climate especially through site-specific way of fertilizer application and INM. Zvomuya et al. (2007) [36] claimed that application of compost rates more than 20.0 tons $\mathrm{ha}^{-1}$ resulted in high $\mathrm{P}$ buildup of phosphorus in the soil i.e. $95.7 \mathrm{ppm}$. The rate of increase of STP level over the initial level in six crop seasons after crop harvest is depicted in Fig 2.

\section{Changes in Soil Potassium}

No beneficial effects of MSWC application regarding soil $\mathrm{K}$ level were observed in cotton-wheat

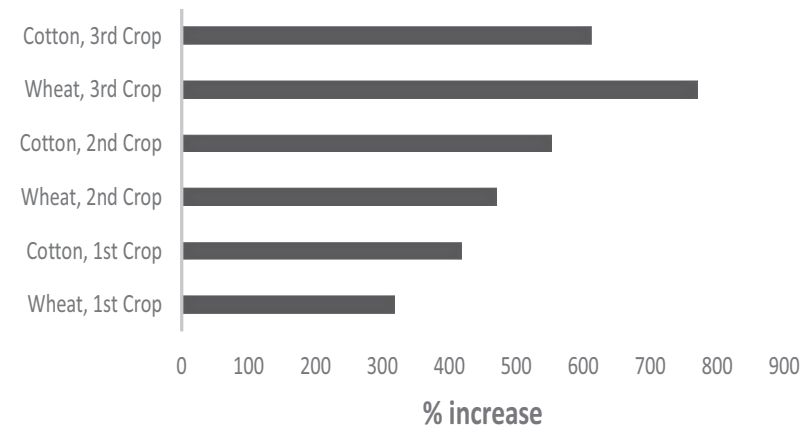

Fig. 2. \% Increase of STP level over initial level in six crop seasons. 
Table 5. Mean indices of soil fertility indicators.

\begin{tabular}{|c|c|c|c|c|}
\hline Technique / Dose & $\mathrm{SOM}$ & $\mathrm{P}_{2} \mathrm{O}_{5}$ & $\mathrm{~K}_{2} \mathrm{O}$ & Mean \\
\hline $\mathrm{T}_{-\mathrm{I}}$ & 1.311 & 1.221 & 0.956 & 1.163 \\
\hline $\mathrm{T}_{\text {II }}$ & 1.151 & 1.333 & 0.992 & 1.159 \\
\hline $\mathrm{T}_{\text {-III }}$ & 0.989 & 1.106 & 1.132 & 1.076 \\
\hline $\mathrm{D}_{\text {-II }}$ & 1.107 & 1.193 & 1.023 & 1.108 \\
\hline Mean & 1.140 & 1.213 & 1.026 & 1.126 \\
\hline
\end{tabular}

system. Statistical non-significant decrease in soil $\mathrm{K}$ level was observed by the site-specific way of fertilizer application $\left(D_{-I I}\right)$ over conventional fertilizer application $\left(D_{-I}\right)$ after three years. The conventional $\left(D_{-I}\right)$ and sitespecific $\left(D_{-I I}\right)$ doses decreased soil $\mathrm{K}$ level by $6.2 \%$ and $3.87 \%$ respectively over initial level (Table 4 ). Total application of MSWC was 21.6-22.0 tons ha ${ }^{-1}$ during three years in INM techniques resulted in decrease soil $\mathrm{K}$ level by $4.70 \%$ to $0.00 \%$ over an initial level of $129 \mathrm{ppm}$. A significant decrease of $10.1 \%$ in soil $\mathrm{K}$ level was observed by the technique of only mineral fertilizer application $T_{-I}$. By season's interpretation, overall $27.13 \%$ decrease in soil $\mathrm{K}$ level was observed after the harvest of the final cotton crop. A significant declining trend is visible in seasons. Probably the $\mathrm{K}$ additions were not adequate to meet the enhanced crops requirement. Mian and Akram (2002) [37] also reported continuous mining of K in the soils of Punjab, Pakistan.

Indexation of Soil Organic Matter, Phosphorus, and Potassium

Soil fertility characteristics play a vital role in the sustainability of a farming system. Values of SOM and soil nutrients status were recorded with improved practices as well as with conventional practices over the whole study period are used as indices of soil fertility and these indices are listed in Table 5. Indices ranking from the best to least favorable were recorded as $\mathrm{P}>\mathrm{SOM}>\mathrm{K}$. No negative impact was noticed. Favorable mean indices were achieved by applying techniques $T_{-I}$ followed by $T_{-I I}$ as compared to $T_{-I I I}$. Mean index $1.163,1.159$ and 1.076 of $T_{-I .} T_{-I I}$ and $T_{-I I I}$ respectively was based on favorable values of $\mathrm{P}$, SOM and $\mathrm{K}$ incorporation of MSWC in fertilizer recipes contributed in enhancing their status. Summing up, all treatments were found advantageous by the indexation with an overall mean index of 1.126 in this cropping system. The enrichment of SOM seems to be the residual effect of the flourished roots due to availability of nutrients applied through mineral fertilizers. The extractable phosphorus, and the SOM increased in twenty years of intensive cultivation by $61.0 \%$ and $51.0 \%$ respectively but potassium decreased by $31.0 \%$ due to use of mineral N\&P fertilizers in Quzhou County [38]. The degrading effects of a cropping system due to soil fertility depletion cannot be mitigated without introduction of new improved technique like INM with cost-effective organic sources and lower herbicides/pesticide use to protect/sustain SOM. Positive site-specific P dose $\left(D_{-I I}\right)$ index (improved practice over conventional routine) i.e. 1.108 was noticed primarily due to favorable indices of all fertility parameters.

\section{Nutrients Balance of Phosphorus and Potassium}

\section{Apparent Balance of Phosphorus}

The apparent balance of phosphorus in a cropping system remained positive in all applied treatments including doses $\left(D_{-I}\right.$ and $\left.D_{-I I}\right)$ and management techniques $\left(T_{-I}, T_{-I I}\right.$ and $\left.T_{-I I I}\right)$ at harvest of first and last crop (Table 6). The doses were enough to gain STP

Table 6. Apparent phosphorus balances.

\begin{tabular}{|c|c|c|c|c|c|}
\hline \multirow{3}{*}{ Technique / Dose } & $\begin{array}{l}\text { Application through mineral } \\
\text { fertilizer plus MSWC }\end{array}$ & $\begin{array}{l}\text { Addition through } \\
\text { irrigational water }\end{array}$ & Total addition & Uptake by crop & Balance \\
\hline & \multicolumn{4}{|c|}{$\mathrm{kg} / \mathrm{ha}$} & \\
\hline & \multicolumn{5}{|c|}{ After $1^{\text {st }}$ wheat Crop } \\
\hline$D_{-I}$ & 44 & 0.7 & 44.7 & 5.6 & +39.1 \\
\hline $\mathrm{D}_{-\mathrm{II}}$ & 85 & 0.7 & 85.7 & 6.1 & +79.6 \\
\hline $\mathrm{T}_{-\mathrm{I}}$ & 65 & 0.7 & 65.7 & 5.2 & +60.5 \\
\hline $\mathrm{T}_{\text {-II }}$ & 65 & 0.7 & 65.7 & 6.3 & +59.4 \\
\hline \multirow[t]{2}{*}{$\mathrm{T}_{\text {-III }}$} & 65 & 0.7 & 65.7 & 6.1 & +59.6 \\
\hline & \multicolumn{4}{|c|}{ After last wheat crop } & \\
\hline $\mathrm{D}_{-\mathrm{I}}$ & 44 & 0.7 & 44.7 & 9.9 & +34.8 \\
\hline $\mathrm{D}_{\text {-II }}$ & 26 & 0.7 & 26.7 & 11.5 & +15.2 \\
\hline $\mathrm{T}_{-\mathrm{I}}$ & 35 & 0.7 & 35.7 & 9.6 & +26.1 \\
\hline $\mathrm{T}_{\text {-II }}$ & 35 & 0.7 & 35.7 & 11.7 & +24.0 \\
\hline $\mathrm{T}_{\text {-III }}$ & 35 & 0.7 & 35.7 & 10.8 & +24.9 \\
\hline
\end{tabular}


Table 7. Apparent potassium balances.

\begin{tabular}{|c|c|c|c|c|c|}
\hline \multirow{3}{*}{ Technique / Dose } & $\begin{array}{l}\text { Application through mineral } \\
\text { fertilizer+MSWC }\end{array}$ & $\begin{array}{l}\text { Addition through } \\
\text { irrigational water }\end{array}$ & Total addition & Uptake by crop & Balance \\
\hline & \multicolumn{4}{|c|}{$\mathrm{kg} / \mathrm{ha}$} & \\
\hline & \multicolumn{5}{|c|}{ Wheat $1^{\text {st }}$ Crop } \\
\hline$D_{-I}$ & 58 & 11 & 69 & 71 & -2 \\
\hline $\mathrm{D}_{\text {-II }}$ & 58 & 11 & 69 & 71 & -2 \\
\hline $\mathrm{T}_{-\mathrm{I}}$ & 58 & 11 & 69 & 73 & +4 \\
\hline $\mathrm{T}_{\text {-II }}$ & 58 & 11 & 69 & 72 & -3 \\
\hline \multirow[t]{2}{*}{$\mathrm{T}_{\text {-III }}$} & 58 & 11 & 69 & 73 & -4 \\
\hline & \multicolumn{5}{|c|}{ Wheat last crop } \\
\hline$D_{-I}$ & 58 & 11 & 69 & 92 & -23 \\
\hline $\mathrm{D}_{\text {-II }}$ & 58 & 11 & 69 & 111 & -32 \\
\hline $\mathrm{T}_{-\mathrm{I}}$ & 58 & 11 & 69 & 68 & +1 \\
\hline $\mathrm{T}_{\text {-II }}$ & 58 & 11 & 69 & 106 & -37 \\
\hline $\mathrm{T}_{\text {-III }}$ & 58 & 11 & 69 & 113 & -44 \\
\hline
\end{tabular}

sufficiency level to fulfill the crop requirement and also besides comparatively lower uptake of the crop. At the time of last wheat harvest, the residual $\mathrm{P}$ effect was found minimized in all the treatments except for $D_{-I}$ where sustained residual effect was recorded. Phosphorus balance in site-specific fertilizer application $\left(D_{-I I}\right)$ appeared less i.e. +15.2 because of residual application of phosphorus recommendations were quite adequate and capable to sustain nutrients soil $\mathrm{P}$ supplying capacity on a long term basis.

\section{Apparent Balance of Potassium}

The apparent $\mathrm{K}$ balance was negative in all treatments except in $T_{-I}$ at harvest of wheat, $1^{\text {st }}$ crop, whereas in $D_{-I}$, nearly sustained situation was observed. The average $\mathrm{K}$ balance ranged from $+1 \mathrm{~kg}$ in $T_{-I}$ of the only use of mineral fertilizers technique to -37 and $-44 \mathrm{~kg} \mathrm{~K} \mathrm{ha}{ }^{-1}$ in $T_{-I I} \& T_{-I I I}$ techniques of INM respectively after harvest of last wheat crop. When MSWC integrated in fertilizer recipe, the $\mathrm{K}$ balance was highly negative as compared to nearly zero balance achieved through only use of mineral fertilizers (Table 7). Despite substantial inputs from irrigation water, the $\mathrm{K}$ balance was remained negative. The total $\mathrm{K}$ uptake by wheat was variable with varied treatments. However, the highly negative $\mathrm{K}$ balance suggests that the system will not be able to sustain the $\mathrm{K}$ supply in the long run. The major fraction of $\mathrm{K}$ uptake, however, remained in straw; thus, recycling of straw can dramatically change the $\mathrm{K}$ balance and would keep it within reasonable limits. However, Eltun et al. (2002) [35] summarized that there were considerable deficits in ecological (organic) systems on the basis of nutrient balance calculations, a fact which must be taken into consideration in the development of the sustainable ecological cropping systems with or without FYM.

\section{Conclusions}

Total application of 22 tons MSWC ha ${ }^{-1}$ during three years in applied treatments resulted in $64 \%$ to $76 \%$ increase in SOM over an initial level of $0.5 \%$ to a level of $0.82-0.88 \%$ by both management techniques of INM with and without pesticide use while conventional and Site-specific doses enhanced SOM level 54\% and 70\% respectively. Statistical significant improved soil test phosphorus (STP) level was observed by the site-specific way of fertilizer application over conventional fertilizer application after three years. The conventional and sitespecific doses enhanced soil test phosphorus (STP) level $394 \%$ and $459 \%$ respectively over initial level. No beneficial effects of MSWC application regarding soil $\mathrm{K}$ level were observed. The conventional and sitespecific doses decreased soil $\mathrm{K}$ level by $6.2 \%$ and $3.87 \%$ respectively over initial level. Indices ranking from the best to least favorable are recorded as $\mathrm{P}>\mathrm{SOM}>\mathrm{K}$. All applied treatments were found advantageous by the indexation with an overall mean index of 1.126 in cotton-wheat cropping system. The apparent balance of phosphorus in a cropping system remained positive in all applied treatments including doses and management techniques at harvest of first and last crop but apparent $\mathrm{K}$ balance was found negative in INM techniques.

\section{Conflict of Interest}

The authors declare no conflict of interest. 


\section{References}

1. PRETTY J., BHARUCHA Z.P. Sustainable intensification in agricultural systems. Annals of Botany 114, 1571, 2014.

2. DASS N., SURI V.K., CHOUDHARY A.K. Site-Specific Nutrient Management Approaches for Enhanced NutrientUse Efficiency in Agricultural Crops. Research \& Reviews: Journal of Crop Science and Technology. Volume 3, Issue 3. 2014.

3. NIZAMI M.I., KHAN N.A. The effect of soil crust on yield of maize crop onthree soil families under rainfed condition. Pak. J. Soil Science. 4 (1-2), 25, 1989.

4. ZIA M.S., BAIG M.B., TAHIR M.B. Soil environmental issues and their impact on agricultural productivity of high potential areas of Pakistan. Science Vision. 4 (2), 56, 1998.

5. SARWAR G., AFTAB M., TAHIR M.A. Efficiency of gypsum and compost for the yield improvement of ricewheat crops in salt stress environment. Int. J. Agric. Appl. Sci. 8 (2), 184, 2016.

6. MOE K., MOH S.M., HTWE A.Z., KAJIHARA Y., YAMAKAWA T. Effects of Integrated Organic and Inorganic Fertilizers on Yield and Growth Parameters of Rice Varieties. Rice Science, 26 (5), 309, 2019.

7. HAMMED T.B., OLORUNTOBA E.O., ANA G. Enhancing growth and yield of crops with nutrientenriched organic fertilizer at wet and dry seasons in ensuring climate-smart agriculture. International Journal of Recycling of Organic Waste in Agriculture. 1, 2019.

8. MASARIRAMBI M.T., MANDISODZA F.C., MASHINGAIDZE A.B., BHEBHE E. Influence of plant population and seed tuber size on growth and yield components of potato (Solanum tuberosum). Int $\mathrm{J} \mathrm{Agr}$ Biol, 14, 545, 2012.

9. ABERA T., TUFA T., MIDEGA T., KUMBI H., TOLA B. Effect of Integrated Inorganic and Organic Fertilizers on Yield and Yield Components of Barley in Liben Jawi District. International Journal of Agronomy, 2018.

10. GENG Y., CAO G., WANG L., WANG S. Effects of equal chemical fertilizer substitutions with organic manure on yield, dry matter, and nitrogen uptake of spring maize and soil nitrogen distribution. PLoS ONE 14 (7), 2019.

11. SHAH F., WU, W. Soil and crop management strategies to ensure higher crop productivity within sustainable environments. Sustainability. 11, 1485, 2019.

12. AAMER M., JAVED Q., MUSTAFA G., MAHMOOD S. Soil fertility management for sustainable agriculture: A case study of District Bahawalangar, Pakistan. Journal of Natural Sciences Research. 19 (5), 57, 2015.

13. KAUSAR R., AZAM M., NAWAZ S., AHMAD I., IQBAL N. Indexing soil fertility status and suitability of groundwater in Sargodha district. Journal of Environment and Agriculture 1 (1), 12, 2016.

14. SONG KE., YONG X., ZHENG X., LV W., QIAO H., QIN Q., YANG J. Effects of the continuous use of organic manure and chemical fertilizer on soil inorganic phosphorus fractions in calcareous soil. Sci Rep. 7, 1164, 2017.

15. SINGH B., RYAN J. Managing fertilizers to enhance soil health. IFA, Paris, France. 2015.

16. LAL R. Soil health and carbon management. Food Energy Secur. 5, 212, 2016.

17. CHANDINI, KUMAR R., KUMAR V., PRAKASH O. The Impact of Chemical Fertilizers on our Environment and Ecosystem. In book: Research Trends in Environmental Sciences, Edition: 2nd, Chapter: 5, 69, 2019.
18. SHAHZAD A.N., QURESHI M.K., WAKEEL A., MISSELBROOK T. Crop production in Pakistan and low nitrogen use efficiencies. Nat Sustain 2, 1106, 2019.

19. FAGERIA N.K. Role of soil organic matter in maintaining sustainability of cropping systems. Commun. Soil Sci. Plant Anal. 43, 2063, 2012.

20. LYNCH D.H. Sustaining soil organic carbon, soil quality and soil health in organic field crop management systems. In: Martin R.C., and MacRae R., editors, Managing energy, nutrients, and pests in organic field crops. CRC Press, Boca Raton, FL. 107, 2014.

21. LAL R. Restoring Soil Quality to Mitigate Soil Degradation. Sustainability. 7, 5875, 2015.

22. TIMSINA, J. Can organic sources of nutrients increase crop yields to meet global food demand? Agronomy. 8, 214, 2018

23. WINKLER B., LEWANDOWSKI I., VOSS A., LEMKE S. Transition towards Renewable Energy Production? Potential in Smallholder Agricultural Systems in West Bengal, India. Sustainability. 10, 801, 2018.

24. GRAHAM R.F., WORTMAN S.E., PITTELKOW C.M. Comparison of organic and integrated nutrient management strategies for reducing soil $\mathrm{N}_{2} \mathrm{O}$ emissions. Sustainability. 2017

25. JONES J.W., ANTLE J.M., BASSO B.O., BOOTE K.J., CONANT R.T., FOSTER I., GODFRAY H.C.J., HERRERO M., HOWITT R.E., JANSSEN S., KEATING B.A., MUNOZ-ARPENA R., PORTER C.H., ROSENZWEIG C., WHEELER T.R. Towards a new generation of agricultural system models, data, and knowledge products: state of agricultural systems science. Agric. Syst., 155, 269, 2017

26. CHOUDHARY A., JAT M.L., NANDAL D.P., SIDHU H. S., SINGH Y., JAT H.S., KAKRALIYA S.K., YADAV A.K. Conservation agriculture practices for enhancing productivity of cotton-wheat system. Haryana J. Agron. 31 (1\&2), 67, 2015.

27. ACHTERBOSCH T., VAN BERKUM S., MEIJERINK G. Cash crops and food security. Contributions to income, livelihood risk and agricultural innovation. LEI Report 2014-015, 57 pp. LEI Wageningen UR (University and Research centre). 2014.

28. REHMAN A., JINGDONG L., SHAHZAD B., CHANDIO A.A., HUSSAIN I., NABI G., IQBAL M.S. Economic perspectives of major field crops of Pakistan: An empirical study Humanities and Social Sciences, Pacific Science Review B. 2016.

29. SINGER J.W., KOHLER K.A., LIEBMAN M., RICHARD T.L., CAMBARDELLA C.A., BUHLER D.D, Tillage and compost affect yield of corn, soybean, and wheat and soil fertility. Agron. J. 96, 531, 2004.

30. AKRAM M., MIAN S.M., AHMAD Z., GILL K.H. Use of fertilizer phosphorus at sufficiency level to sustain soil fertility without environmental repercussions. Pak. J. Soil Sci. 18, 19, 2000.

31. MCLEAN E.O., OLOYA T.O., MOSTAGHIMI S. Improved fertilizer recommendations based on two-step alternative usage of soil tests; I. Recovery of soil equilibrated phosphorus. Soil Sci. Soc. Amer. J. 46, 1193, 1982.

32. WALKLEY A., BLACK C.A. An estimation of Degtareff methods for determining soil organic matter and a proposed modification of the chromic acid titration method. Soil Sci. 37, 29, 1934.

33. OLSEN S.R., COLE C.V., WATANABE F.S., DEAN L.A. Estimation of available phosphorus in soils by extraction 
with sodium bicarbonate. USDA Circular 939, 1-19. Gov. Printing Office Washington D.C. 1954.

34. BROWN J.R., WARENCKE D.D. Recommended cation tests and measures of cation exchange capacity. In: Recommended chemical soil test procedures for North Central Region. Bull. No. 499. (ed.) W.C. Dahnke, 15-16 North Dakota Agric. Exp. Stn., Fargo, ND. 1988.

35. ELTUN R., KORSÆTH A., NORDHEIM O. A comparison of environmental, soil fertility, yield, and economical effects in six cropping systems based on an 8-year experiment in Norway. 90, 155, 2002.
36. ZVOMUYA F., LARNEY F.J., DEMAERE P.R., OLSON A.F. Reclamation of abandoned natural gas well sites with organic amendments: Effects on soil carbon, nitrogen, and phosphorus. Soil Sci. soc. Am. J. 71, 1186, 2007.

37. MIAN S.M, AKRAM M. In. Annual Report, Soil and Water Testing, Laboratory, Agriculture Department, Lahore (Pakistan). 7, 2002.

38. CHEN J., YU Z., OUYANG J., VAN MENSVOORT M.E.F. Factors affecting soil quality changes in the North China Plain: A case study of Quzhou County. 91, 171, 2006. 
